\title{
NOTES ON AUSTRALIAN ABORIGINAL STONE WEAPONS AND IMPLEMENTS.
}

\author{
By R. Etheridge, Jun. \\ (Paleontologist to the Australian Museum, and Geological \\ Survey of New South Wales.)
}

v.-Chips used in wood carving by the Marathon Tribe, Central Queensland.

(Plate XIII., fig. 13.)

The two chips exhibited were given to me by Mr. George Sweet, of Brunswick, Melbourne, who saw them used by "Old Jerry," of the Telebra Tribe, at Marathon, Central Queensland, to produce the indented lines ornamenting wooden weapons. They are composed of a black brecciated chert, with a glossy lustre and a subconchoidal fracture, but appear to have been fortuitous fragments chipped from larger masses, and are more or less triangular in form. Large numbers of such chips are found in some districts of Australia, often at great distances apart, and their application has been so variously assigned, such as for cutting scars, skinning, as fragments of tomahawks, and for making jagged spears, that it is satisfactory to be able to figure fragments which have been actually seen in use for a definite purpose. A very interesting account of the distribution and mode of occurrence of similar chips over the surface of some parts of Victoria may be found in the late Mr. R. B. Smyth's "Aborigines of Victoria." *

Mr. Sweet informs me that the chips are held tightly between the fingers of the right hand, the weapon to be worked reposing in the left, and supported on the left arm. The chip is then used as a chisel, the carving, in the practised hand of the black, proceeding with great rapidity.

This method of hand-carving is quite different to that pursued by the Victorian natives by means of the implement called the 
leange-walert, formed of the lower jaw of an opossum, and described by the late Mr. R. B. Smyth.*

\section{vi.-An apparently undescribed form of Stone Axe. (Plate xII., fig. 14.)}

The following very remarkable form of stone hatchet or tomahawk is, so far as I know, unnoticed. It consists of a head of stone, perfectly resembling in shape the previously described Mikaknives, $\uparrow$ but composed of a hard, close-grained, rather flesh-coloured granular quartzite, and produced by fracture. The heads, of which there are two, are generally similar to the stone-headed spears from North Australia, figured by the late Mr. R. B. Smyth, $\ddagger$ similar Australian weapons, illustrated by Mr. J. G. Wood, M.A., § but without locality, and the obsidian spear-heads of the Admiralty Islands.

One of the axe-heads is eight inches long, and the other seven inches; the longer being two inches wide at the base, and the shorter two and a quarter inches. One face of each is practically flat, the other strongly angular in the middle line. In the shorter of the two this line is replaced by a facet towara's the base of the axe. The heads are mounted in withys, artificially grooved, and passed round their bases, formed of some tough fibrous plant, and secured by a mass of black gum. One of the handles is nineteen inches long, and the other eighteen, the two parts being held together near the middle, and at the free extremities, which are pointed, by string, again secured by gum. On the whole, these weapons, although ill-balanced, are formidable, and capable of dealing a most destructive blow.

This appears to be quite an exceptional form of tomahawk amongst the Aborigines, and is an adaption for this purpose of a spear-head pattern. The shape is clearly that of the Mika-knives, but the weight, proportions, and size are altogether different. I am not acquainted with the figure of such a hatchet, but Smyth

* “A Aborigines of Victoria,” 1878, I., p. 349, f. 164.

+ See Proc. Linn. Soc. N. S. Wales, antea, p. 251.

+ " Aborigines of Victoria," 1878, I., p. 308, f. 85.

$\S$ “Nat. Hist. Man. Australia,” \&c., 1870, p. 38, f. 1 \& 5. 
gives* an illustration of a similar head, made of an identical rock, mounted with gum at the end of a handle made of a single piece. The entire weapon, handle and head, only measures eight inches in length, and is therefore much smaller than the present form. It is called by Smyth a "stone knife," and is used by the inhabitants of Booloo and Cooper's Creek. Amongst the Niika-knives presented to the Australian Museum by Mr. Dunlops is an unhafted blade, preserved in a bark sheath, made of a similar granular, flesh-coloured quartzite to the above, but having the proportions of the other undoubted Mika-knives, and not of the present weapons. It is much too coarse in texture, and rough on the edge, to be employed in a similar manner, and is, therefore, in all probability, a smaller unmounted example of the present hatchet. It is four and a half inches long by two wide.

The method of hafting clearly marks these weapons as axes, or hatchets, but the entire departure from the ordinary form of Mogo, or tomakawk, is a very interesting point. The two halves of the handles are twice tied, as is usual in such weapons, but in the middle and at the end, instead of under the head and at the end.

\section{vii. - Stone axe-heads from the Lennard River, King's Sound,}

N. W. Australia.

$$
\text { (Plate xiv., fig. 15.) }
$$

I am indebted to the kindness of Mr. W. W. Froggatt for an opportunity of describing a suite of five stone axe-heads from the Lennard River, obtained by him during his late collecting tour in that district. The axe-heads are all of one type, and formed from selected oblong flattened pebbles. They are all more or less ground towards the cutting extremity, but it would appear that the original ihickness and bulk of the pebbles has been reduced by knocking off flakes, especially in the two smaller specimens. Two still bear traces of the gum used for mounting them in their handles, and one is very slightly grooved for the reception of its hafting. The stones employed are a dense black basalt, but before manipulation the pebbles had evidently undergone much fluviatile action. The measurements of the three largest are as follows :- 


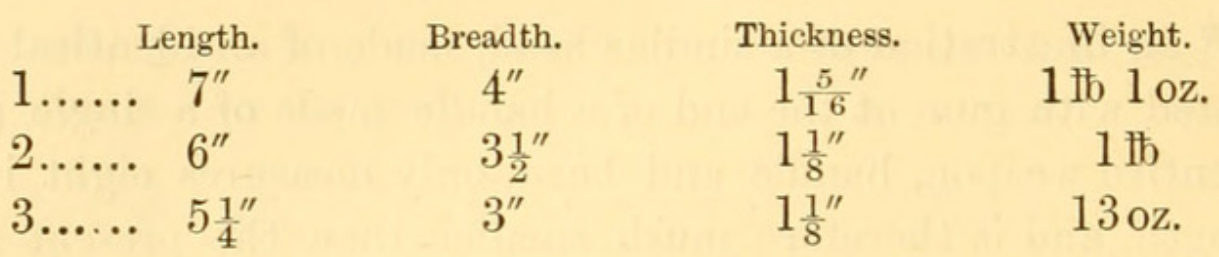

The largest is really a fine weapon, but neither this nor any of the others can lay claim to that excellency of finish displayed by many of the tomahawks of Victoria and New South Wales. The curve of the cutting edge, it is true, is fairly good, but the grinding to produce the bevel has been roughly executed.

In their peculiarly flattened and oval form these axe-heads resemble weapons figured* by Smyth from Lake Tyers, but the disposition of the cementing gum indicates that our axe-heads were single, not double, as in the case of those from that locality ; another figured by Evans† from "Northern Australia ;" and also another by Smyth $\ddagger$ from the Burdekin River, North Queensland, but with stronger traces of percussion in its manufacture.

\section{viii.-A Talismanic Stone, or Teyl, from Cooktown.}

It has long been known that the "Coradges," priests, or "medicine men," usually, in preference to other members of a tribe, carried talismanic stones, as a rule, concealed in the girdle. These were seldom willingly shown to strangers, never to the women, but were supposed to possess extraordinary powers in working enchantments, as a preservative against sickness, and generally as a charm. They are valued according to size, and were usually made use of at night.

These stones are not necessarily all of one kind, for Mitchell mentions both "crystals of quartz, or other shining stones," and Grey\| says, "shining stones or pieces of crystal," called teyl. Threlkeld in his "Vocabulary" mentions a round ball, about the

* “"Aborigines of Victoria," 1878, pp. 366-367.

† " Ancient Stone Implements, \&c.," 1872, p. 150, f. 105.

‡ " Aborigines of Victoria," 1878, p. 367, f. 180.

§ “Two Expeds. Int. E. Australia,” 1838, II., p. 338.

|| “Journ. Two Expeds. Discovery in N.W. \& W. Australia," 1841, II., p. 340.

- Page 88 (teste R. B. Smyth). 
size of a cricket ball, carried in a small net suspended from the girdle, and called mur-ra-mai. By the Sydney blacks such stones were known as krardgee-kibba, or Doctor stone; by the Yass, Murrumbidgee, and Tumut Aborigines, they were termed merudagalle. * In the Murrumbidgee tribes the stones are said by Mr. J. Manning $\dagger$ to decend from father to son, and to give semi-divine authority. According to Dr. John Fraser $\ddagger$ similar pieces of rock crystal were used in the ceremony of the Bora, one or more pieces being given to the bombat or novice. This took place in the Yuin tribe on the S.E. coast.

The specimen now in my hands was obtained by Mr. George Sweet, of Brunswick, Melbourne, at Cooktown. The use of these talismanic stones so far north is already known, Leichhardt having recorded their use on the Lynd River.§ Mr. Sweet's specimen consists of a compound prismatic crystal of quartz, frosted and opaque at the base, but clear towards the apices of the pyramids, and more or less transparent. It measures three and a half inches in length, is one and a half inches in diameter, and weighs four and a half ounces. This quite equals in size the stone described by the Rev. Dr. Turner, Bishop of Grafton and Armidale, $\|$ obtained from a dilly-bag at Armidale, measuring $3 \frac{1}{4}$ in. $\times 1 \frac{1}{4}$ in. $\times 3$ in. ; or the still larger egg-shaped stone described by Smyth 9 from Gippsland, four inches in length, and two and a half in breadth, and called bulk. The almost universal use of these talismanic stones throughout Australia is a point of great interest.

\section{ix.-Pigment Ochres from the Lerinard River, King's Sound,}

N. W. Australia.

The colours formerly employed by the Aboriginals in the ornamentation of their weapons and implements, and adornment of

* Bennett, “Wanderings in Australia,” 1834, I., p. 191.

† Journ. R. Soc. N. S. Wales for 1882 [1883], XVI., p. 161.

‡ Journ. R. Soc. N. S. Wales for 1882 [1883], XV1., p. 207.

$\S$ "Journal of an Overland Expedition in Australia from Moreton Bay Port Essington," 1847, p. 270.

॥ Proc. Linn. Soc. N. S. Wales for 1885 [1886], X., pt. 2, p. 188.

ๆ "A Aborigines of Victoria," 1878, I., p. 386. 
their bodies, were black, white, red, and yellow. These colours were usually derived from the decomposition of certain rocks resulting in the formation of clays. Yellow, red, and white were generally used for painting the person, and the two latter colours for weapons, although the first was employed at times, especially according to Smyth, throughout Northern Australia.

Mr. Froggatt has brought both red and yellow colour-stones from the Lennard River, taken from the dilly-bags of the Aborigines. The former consists of a highly ferruginous blood-red gritty rock, which, from the rounded condition of its edges, shows that it has undergone a good deal of friction, and in its present shape and condition resembles a piece of french-chalk, as used by clothiers for marking cloth. The latter is simply a small semidecomposed ironstone nodule, the concentric layers still showing on a fractured surface. The edges of this specimen have all the appearance of having been cut with some sharp instrument.

\section{EXPLANATION OF PLATES.}

Fig. 13.-Chip used by Marathon blacks for carving wooden implements. Coll. Sweet, Melbourne; Mining and Geol. Mus. Nat. size.

Fig, 14.-Undescribed form of Stone Axe, formed of a flesh-coloured quartzite, and mounded in a withy wound round it; North Central Queensland.? Coll. Australian Mus. Little less than half nat size.

Fig. 15.-Head of Tomahawk of black basalt; Lennard River, Kimberley. Coll. Froggatt. Slightly reduced. 


\section{$2 \mathrm{BHL}$ Biodiversity Heritage Library}

Etheridge, Robert and Melo-Costa, Wanessa de. 1890. "Notes on Australian aboriginal stone weapons and implements." Proceedings of the Linnean Society of New South Wales 5, 367-372. https://doi.org/10.5962/bhl.part.18642.

View This Item Online: https://www.biodiversitylibrary.org/item/22899

DOI: https://doi.org/10.5962/bhl.part.18642

Permalink: https://www.biodiversitylibrary.org/partpdf/18642

\section{Holding Institution}

MBLWHOI Library

\section{Sponsored by}

MBLWHOI Library

\section{Copyright \& Reuse}

Copyright Status: NOT_IN_COPYRIGHT

This document was created from content at the Biodiversity Heritage Library, the world's largest open access digital library for biodiversity literature and archives. Visit BHL at https://www.biodiversitylibrary.org. 